\title{
Cytotoxic and Apoptotic Effects of Extracts of Artemisia ciniformis Krasch. \& Popov ex Poljakov on K562 and HL-60 Cell Lines
}

\author{
Zahra Tayarani-Najaran', Zahra Hajian ${ }^{1,2}$, Mahdi Mojarrab ${ }^{3}$, Seyed Ahmad \\ Emami $^{2 *}$
}

\begin{abstract}
Artemisia, as one of the largest genera in the tribe Anthemideae of the Asteraceae comprises an important part of Iranian flora. While cytotoxic and apoptotic properties have already been reported for some species of the genus there is not any report on cytotoxic effects of $A$. ciniformis. Petroleum ether (40-60), dichloromethane, ethyl acetate, ethanol and ethanol-water (50:50) extracts of the aerial parts of $A$. cinformis were subjected to cytotoxic and apoptotic evaluations on two cancer human cell lines (K562 and HL-60) and on J774 normal cells. Among multiple extracts evaluated for cytotoxicity, dichloromethane $\left(\mathrm{CH}_{2} \mathrm{Cl}_{2}\right)$ and petroleum ether (PE) extracts were shown to possess the highest anti-proliferative effects on HL-60 and K562 cells with $\mathrm{IC}_{50}$ values of 31.3 and $25.5 \mu \mathrm{g} / \mathrm{ml}$ respectively. Apoptosis induction verified by sub-G1 peaks was seen in flow cytometry histograms. Increase in the amount of Bax protein, formation of DNA fragments, and cleavage of PARP to 24 and 89kDa sub units all confirmed induction of apoptosis by $A$. cinformis extracts. Taken together according to the result of the present study some extracts of $\boldsymbol{A}$. cinformis could be considered as sources for natural cytotoxic compounds and further mechanistic and phytochemical studies are recommended to fully understand the underlying mechanisms of cnacer cell death as well as identification of responsible phytochemicals.
\end{abstract}

Keywords: Artemisia ciniformis - asteraceae leukemic cell lines - petroleum ether extract - dichloromethane extract

Asian Pac J Cancer Prev, 15 (17), 7055-7059

\section{Introduction}

Increase in prevalence of cancer cases has been associated with the expansion of industrial, chemical and radioactive pollutants, also the gap between human being and nature (Colditz and Wei, 2012; Fasinu and Orisakwe, 2013). Despite the progress in the field of medicinal chemistry and development in the synthesis of several new therapeutic compounds, the role of plants and phytochemicals can not be ignored in pharmaceutical sciences (Cerella et al., 2014). Due to the presence of compounds with cytotoxic and anti-tumor activity in some plants and significant efficacy of plant derived compounds in inhibition and treatment of cancer, as well as the amazing diversity of natural compounds in plants, researches to find new phytochemicals and to evaluate their biological effects is essential and a research priority (Tayarani-Najaran et al., 2011; Wegiera et al., 2012; Sehitoglu et al., 2014).

Artemisia is a genus belonging to the family Asteraceae Compositae with commonly fragrant species. Some species such as A.dracunculus L. are kitchen plants and used for culinary purposes. A. absinthium L. and A. vulgaris L. have long been implicated as medicinal herb, while some others are cultivated as ornamental species (Bora and Sharma, 2011). Various species of Artemisia have been extensively studied for their biological activities. Among the about 400 species of the genus, 34 species are grown in Iran, with two being endemic to this country (Ghahreman and Attar, 1999; Emami and Aghazari 2011). Some species of the genus Artemisia have been utilized widely for food and drug purposes in both traditional and modern markets. They have value as food additives for culinary purposes, antimicrobial or antiviral (Aniya et al., 2000; Kordali et al., 2005a; 2005b), antihepatotoxic, anti-malarial and antiinflammatory agents (Gilani et al., 2005; Bora and Sharma 2011; Abad et al., 2012). Artemisia is a rich source of plant phytochemicals, including flavonoides, coumarins, sterols, polyacethylenes, mono- and sesquiterpenes, and sesquitrpene lactones (Tan et al., 1998; Bora and Sharma, 2011). Artemisia ciniformis Krasch. \& Popov ex Poljakov. is one of Artemisia species growing wildly in Iran (Ghahreman and Attar, 1999). Volatiles from the aerial parts of $A$. ciniformis were identified as myrcene 
(19.3\%), linalool (13.5\%), camphor (13.1\%) and davanone (12.6\%) (Rustaiyan et al., 2007). Another study on the composition of the essential oil of A. ciniformis has revealed the presence of davanone $(29.6 \%)$, myrcene $(14.4 \%)$, camphor $(10.6 \%), p$-cymene $(9.6 \%)$, and linalool (8.6\%) (Firouzni et al., 2008). Dichloromethane fraction of $A$. ciniformis showed the highest cytotoxicity on the gastric cancer cell line in comparison with six other Artemisia species (Emami et al., 2010). Further study on A. ciniformis extracts showed the outstanding cytotoxicity of dichloromethane fraction against a wide range of cancer cell lines (Taghizadeh Rabe et al., 2011). Significant in vitro leishmanicidal activity for the ethanol extract of A. ciniformis has been reported (Emami et al., 2012). Nontoxic concentration of ethyl acetate, ethanol and ethanol-water $(1: 1 \mathrm{v} / \mathrm{v})$ extracts of $A$. ciniformis have shown protective effect on $\mathrm{H}_{2} \mathrm{O}_{2}$-induced cytotoxicity in $\mathrm{H} 9 \mathrm{c} 2$ cells (Mojarrab et al., 2013). According to the cytotoxic effects reported for A. ciniformis, it is of value to study the mechanisms responsible for this cell toxicity. To the best of our knowledge, there has not been any similar study done on the different fractions of A. ciniformis and its mechanism on cell death. As apoptosis is the desired pathway of cell death in cancer treatment we have designed this study to elucidate if apoptosis is involved in growth inhibitory activity of $A$. ciniformis extracts.

\section{Materials and Methods}

\section{Reagents and chemicals}

AlamarBlue $^{\circledR}$ (resazurin) from Sigma (Saint Louis, MO, USA); RPMI-1640 and FBS from Gibco; $\beta$-actin and PARP antibodies, anti-rabbit IgG and HRP linked antibody from CellSignaling technology (Boston, USA); ECL Western blotting detection reagent from Bio-RaD (USA); the fluorescent probe propidium iodide (PI), protease inhibitor cocktail, phosphatase inhibitor cocktail, sodium citrate, Triton X-100, phenylmethylsulfonyl fluoride and QuantiPro BCA Assay Kit from Sigma (Steinheim, Germany); All the solvents used for extraction were purchased from Caledon and Scharlau.

\section{Plant material}

Aerial parts of A. ciniformis were collected from Tandoureh National Park (Razavi Khorasan province, Iran) in September 2010. Samples were identified by Dr. V. Mozaffarian (Research Institute of Forest and Rangelands, Tehran, Iran). The voucher specimen (No. 12569) has been deposited in the herbarium, Department of Pharmacognosy, Faculty of Pharmacy, Mashhad University of Medical Sciences, Mashhad, Iran.

\section{Preparation of extracts and fractions}

The dried powdered aerial parts $(80 \mathrm{~g})$ of $A$. ciniformis were extracted with petroleum ether (40-60), dichloromethane, ethyl acetate, ethanol and ethanol-water $(1: 1 \mathrm{v} / \mathrm{v})$ respectively (sequential maceration with $3 \times$ ca. $0.8 \mathrm{~L}$ of each solvent). The extracts were filtrated with filter paper and dried using rotary evaporator at a reduced pressure at a temperature below $450 \mathrm{C}$ to yield 4.14, 9.08, $0.37,2.54$ and $16.87 \mathrm{~g}$ of each extract.

\section{Cell cultures and treatment agent}

HL-60 and K562 human leukemic cancer cell lines were purchased from Pasture Institute (Tehran, Iran) and preserved in RPMI-1640 medium with $10 \% \mathrm{v} / \mathrm{v}$ fetal bovine serum and $100 \mathrm{u} / \mathrm{ml}$ penicillin and $100 \mathrm{mg} / \mathrm{ml}$ streptomycin at $37^{\circ} \mathrm{C}$ in a humidified atmosphere of $5 \%$ $\mathrm{CO}_{2}$ and $95 \%$ of air.

\section{In vitro Cell Viability}

The alamarBlue ${ }^{\circledR}$ is composed of resazurin, a reagent which can be reduced in live cells indicating the rate of viability in culture cells. Once resazurin is converted to reduced form (resorufin) the ratio of red color product is proportional to live cells (O'Brien et al., 2000). About $5 \times 10^{4} \mathrm{~K} 562$ and $10^{5} \mathrm{HL}-60$ cells were seeded in each well of 96-microwell plate and subjected to treatment with various concentrations of each extract of $A$. ciniformis. J774 cell line was selected to use as non-malignant cell line. After $48 \mathrm{~h}$ incubation, alamarBlue ${ }^{\circledR}$ was added to each well according to the manufacturer's instructions. After $4 \mathrm{~h}$ incubation, the cell viability was determined by reading the absorbance at $570 \mathrm{~nm}$ and $600 \mathrm{~nm}$ using an ELISA microplate reader (Awareness, Palm City, FL, USA). The cytotoxicity of $A$. ciniformis extracts was expressed as $\mathrm{IC}_{50}$, which was calculated using Graph Pad Software (Graph Pad prism 5 software) and presented as mean \pm SEM of three separate experiments with three replicates for each concentration of $A$. ciniformis extracts.

\section{PI staining}

The method was performed according to the previously reported assay (Tayarani-Najaran et al., 2013; Nicoletti et al., 1991). Briefly, $10^{6} \mathrm{~K} 562$ and HL-60 cells were seeded in each well of a $24-w e l l$ plate and treated with petroleum ether $(12.5,25$ and $50 \mu \mathrm{g} / \mathrm{ml})$ and $\mathrm{CH}_{2} \mathrm{Cl}_{2}(25,50$ and 100 $\mu \mathrm{g} / \mathrm{ml})$ extracts of $A$. ciniformis for $48 \mathrm{~h}$. Floating and adherent cells were then harvested and incubated at $4^{\circ} \mathrm{C}$ overnight in the dark with $750 \mu \mathrm{L}$ of a hypotonic buffer (50 $\mu \mathrm{g} / \mathrm{mL}$ PI in $0.1 \%$ sodium citrate plus $0.1 \%$ Triton X-100) before flow cytometric analysis using a flow cytometer (Becton Dickinson). 104 events were acquired with flow cytometer.

\section{Western blotting analysis}

About $10^{7}$ HL-60 cells were treated with different concentrations of petroleum ether and $\mathrm{CH}_{2} \mathrm{Cl}_{2}$ extracts $(12.5,25$ and $50 \mu \mathrm{g} / \mathrm{mL}$ of the first extract, 25,50 and $100 \mu \mathrm{g} / \mathrm{mL}$ of the second one) for $48 \mathrm{~h}$. The cells rinsed and harvested using cool PBS for three times, the cell pellet was resuspended in a lysis buffer containing 50 $\mathrm{mM}$ Tris- $\mathrm{HCl}(\mathrm{PH}=7.4), 150 \mathrm{mM} \mathrm{NaCl}, 1 \%$ Triton $\mathrm{X}-100,1 \mathrm{mM}$ EDTA, $0.2 \%$ SDS, $1 \%$ Protease inhibitor cocktail, $1 \%$ phosphatase inhibitor cocktail and $1 \mathrm{mM}$ phenylmethylsulfonylfluoride and left on ice for $30 \mathrm{~min}$. After centrifugation at $10000 \mathrm{rpm}$ for $20 \mathrm{~min}$ at $4^{\circ} \mathrm{C}$, the cell lysate was gathered and protein concentration was determined according to the Bio-Rad Protein Assay kit. Balanced amount of proteins was subjected to $12 \%$ SDS-page $(\mathrm{W} / \mathrm{V})$. The proteins were transferred to a polyvinylidene fluoride (PVDF) membrane and subjected to immunoblotting using Bax, $\beta$-actin and PARP antibody 
as primary antibodies while anti-rabbit IgG and HRPlinked antibody were used as secondary antibodies. Bcl-2. Bax protein band and PARP cleavage in HL-60 cells were detected by enhanced chemiluminescence using the ECL western blotting detection reagent. Images were quantified using Gel-pro Analyser V.6.0 Gel Analysis software (Media Cybernetics, InC, Bethesda, MD).

\section{Statistical analysis}

One way analysis of variance (ANOVA) and Bonferroni post hoc test were used for data analysis. All the results were expressed as mean \pm SEM and $\mathrm{p}$ values below 0.05 were considered statistically significant.

\section{Results}

Cytotoxicity of various extracts

Different extracts of $A$. ciniformis were examined for cytotoxic potential on K562, HL-60 and normal cell lines (J774). These cells incubated in $37^{\circ} \mathrm{C}$ and $5 \% \mathrm{CO}_{2}$ with various concentrations of different extracts of $A$. ciniformis (25- $100 \mu \mathrm{g} / \mathrm{ml})$ for $48 \mathrm{~h}$.

Results demonstrated that some extracts decreased cell viability in a concentration-dependant manner. Among different extracts, $\mathrm{CH}_{2} \mathrm{Cl}_{2}$ extract demonstrated the highest cytotoxicity on HL-60 cells while petroleum ether extract

Table 1. $\mathrm{IC}_{50}$ values $(\boldsymbol{\mu g} / \mathrm{mL})$ for Different Extracts of A. Ciniformis in HL-60 and K562 Cell Lines.

\begin{tabular}{lccccc}
\hline & \multicolumn{5}{c}{ Extracts } \\
Cell line & PE & $\mathrm{CH}_{2} \mathrm{Cl}_{2}$ & EtOAc & EtOH & EtOH/H \\
\hline K562 & 25.53 & $>200$ & $>200$ & $>200$ & $>200$ \\
HL-60 & 105.20 & 31.33 & 165.20 & $>200$ & $>200$ \\
\hline
\end{tabular}

exhibited the most potent cytotoxic activity on K562 cells, but minimal effect on normal cells (Figure 1). $\mathrm{IC}_{50}$ values $(\mu \mathrm{g} / \mathrm{mL})$ for different extracts of A. ciniformis in HL-60 and K562 cells are presented in Table 1.

Apoptosis induction by $\mathrm{CH}_{2} \mathrm{Cl}_{2}$ and petroleum ether
extracts

Apoptosis in K562 and HL-60 cell lines was detected with flow cytometry by the aid of PI staining test. Cells incubated with various concentrations of $\mathrm{CH}_{2} \mathrm{Cl}_{2}(25,50$ and $100 \mu \mathrm{g} / \mathrm{ml})$ and petroleum ether $(12.5,25$ and 50 $\mu \mathrm{g} / \mathrm{ml}$ ) extracts of $A$. ciniformis for $48 \mathrm{~h}$. Comparison of Sub-G1 peak of treated cells to that of untreated control cells in flow cytometry histograms confirmed the induction of apoptosis in treated cells (Figure 2).

\section{Western blotting}

The cleavage of $116 \mathrm{kDa}$ PARP-1 to 89 and $24 \mathrm{kDa}$ fragments was used as an indicator of apoptosis. $48 \mathrm{~h}$ treatment of HL-60 cells with different concentrations (25, 50 and $100 \mu \mathrm{g} / \mathrm{ml}$ ) of $\mathrm{CH}_{2} \mathrm{Cl}_{2}$ extract resulted in cleavage of aforementioned protein. The same result was recorded after treatment of K562 cells with different concentrations $(12.5,25$ and $50 \mu \mathrm{g} / \mathrm{ml}$ ) of petroleum ether extract (Figure 3). Bax proteins play a determining role to control the release of cytochrome $\mathrm{c}$ and to initiate the apoptosis via the mitochondrial pathway (Renault and Manon, 2011). Different concentrations of dichloromethane $(25,50$ and $100 \mu \mathrm{g} / \mathrm{ml})$ and petroleum ether $(12.5,25$ and $50 \mu \mathrm{g} / \mathrm{ml})$ extracts enhanced the expression of Bax protein in HL-60 and K562 cells cells in a concentration-dependent manner respectively (Figure 3).
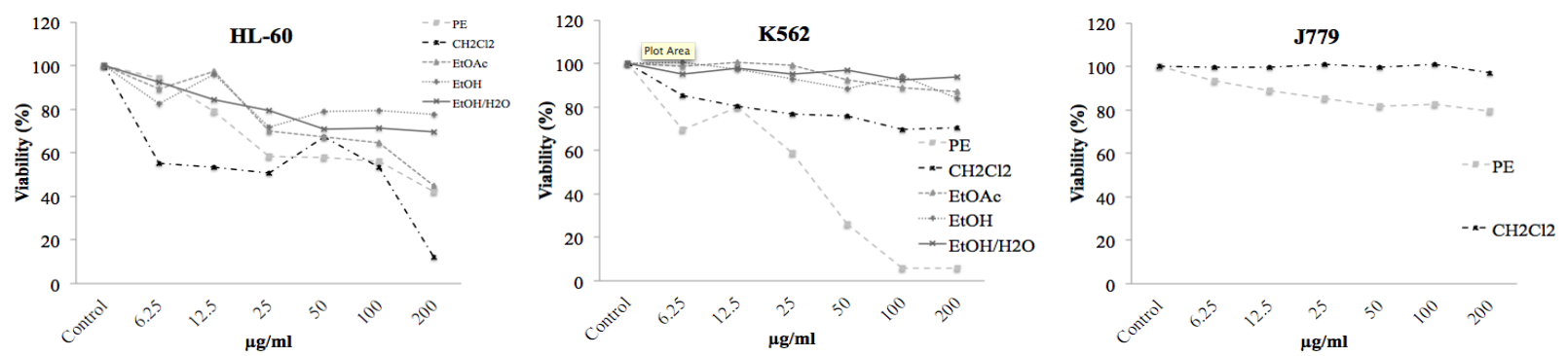

Figure 1. The Dose-Dependent Effects of Different Extracts of A. ciniformis on the growth of K562 and HL-60 cells as well as normal $\mathrm{J} 774$ cells. $\mathrm{PE}, \mathrm{CH}_{2} \mathrm{Cl}_{2}$ and EtOAc extracts exhibited cytotoxic activity against apoptosis-proficient HL-60 and apoptosis-resistant K562 cells with much less cytotoxic effects on normal J774 cells. Values were mean \pm SEM of at least three independent experiments, each in triplicates

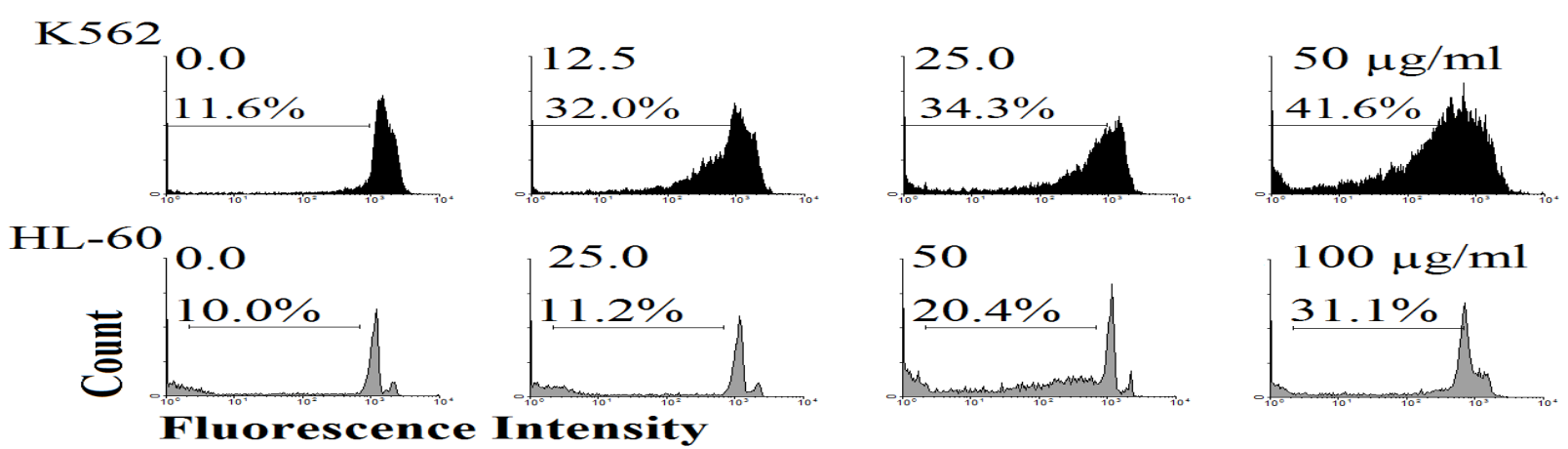

Figure 2. PI Staining and Flow Cytometric Analysis of $\mathrm{CH}_{2} \mathrm{Cl}_{2}$ Extract $(25,50,100 \mu \mathrm{g} / \mathrm{ml})$ Induced Apoptosis in HL-60 cells and Petroleum Ether Extract $(12.5,25,50 \mu \mathrm{g} / \mathrm{ml})$ Induced Apoptosis in K562 


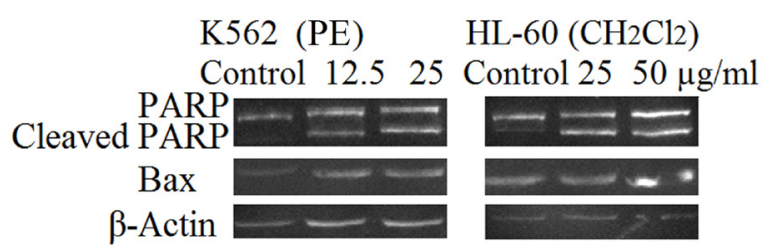

Figure 3. Proteolytic Cleavage of Poly (ADP-ribose) Polymerase (PARP) and Increasing Expression of Bax Protein in HL-60 after 48h Exposure to $\mathrm{CH}_{2} \mathrm{Cl}_{2}$ Extract $(25,50 \mu \mathrm{g} / \mathrm{ml})$ and $\mathrm{K562}$ Cells after $48 \mathrm{~h}$ Exposure to Petroleum ether Extract (12.5 and $25 \mu \mathrm{g} /$ ml). $\beta$-Actin was used as a loading control. All Western blots were representative of three independent experiments

\section{Discussion}

This is the first mechanistic study on the cytotoxicity and apoptosis induction by A. ciniformis. However, other studies have been done on the cytovtoxicity of the different species of the plant Artemisia. Concentration dependent cytotoxicity of the essential oil of $A$. indica against four cancer cell lines A-549, THP-1, Caco-2 and HEP-2 has been reported (Rashid et al., 2013). Essential oils of A. absinthium which contained higher amounts of trans-sabinyl acetate and cis/trans-thujones exhibited more toxicity on brine shrimp (Judzentiene et al., 2012). Moreover, the essential oils of A. capillaris and A. herba$a l b a$ are regarded as good candidates for further study, because they showed significant anti-proliferative activity against the human oral cancer and acute lymphoblastic leukaemia (CEM) cell lines respectively (Cha et al., 2009; Tilaoui et al., 2011). Dichloromethane extracts of A. апnиа exhibited higher cytotoxicity in comparison with methanol extracts against HeLa cancer cells (Efferth et al., 2011). The $\mathrm{CH}_{2} \mathrm{Cl}_{2}$ fraction from A. sacrorum was more cytotoxic than eight other fractions towards HepG2, HT-29 and MCF-7 cells (Piao et al., 2012). Ethanol extracts of $A$. argyi, А. аппиа and $A$. afra exhibited activity against $\mathrm{P} 388$ murine leukemia, molt-4 human leukemia, U937, and HeLa cancer cell lines, respectively (Lee and Vairappan, 2011; Singh et al., 2011; Spies et al., 2013). Similar studies on potential use of Artemisia genus and its active constituents in cancer therapy reported the synergistic cytotoxicity of artesunate from the traditional Chinese herb Artemisia annua in combination with triptolide or allicin in pancreatic cancer or osteosarcoma cell lines respectively (Liu and Cui, 2013; Jiang et al., 2013).

In our study, we have shown that petroleum ether and $\mathrm{CH}_{2} \mathrm{Cl}_{2}$ extracts from A. ciniformis were cytotoxic and apoptotic against HL-60 and K562 cells. The highest cytotoxic effect of these two extracts among the other solvent extracts used in this study shows the ability of petroleum ether and $\mathrm{CH}_{2} \mathrm{Cl}_{2}$ solvents to extract potent phytochemicals, which may be due to the semi/non polarity nature of the solvents.

In the present study, some extracts of A. ciniformis showed apoptosis inducing activity that has confirmed the need for further analytical and mechanistic studies of the plant. As we expected the cytotoxicity of the extracts on HL-60 cells were more than that was observed in K562 cells. This is associated with the differences between these two cell lines (Munker et al., 1997). K562 cells lack Fas receptors and are apoptosis resistant while HL-60 cells are apoptosis proficient.

Once apoptosis cascade is started, signals from either extrinsic or intrinsic pathway promote enzymatic activation of substrates. Caspase are cysteine enzymes, which play the most important role in apoptosis promotion. Each of the extrinsic or intrinsic pathways recruits their own mediators. While caspase 9 is the mediator of the mitochondrial pathway, death receptors join to caspase 8 to activate the enzyme activation. Caspase 8 can affect mitochondria via truncation of Bid, which interrupts the membrane potential. The mitochondrial membrane potential is also affected by changes in the balance of presented in the bilayer membrane space of pro-apoptotic and anti-apoptotic proteins mitochondria. Both the extrinsic and connect via activation of 3 , which create changes in critical nuclear enzyme activity and DNA degradation that lead to programmed mode of cell death (Parsons et al., 2010). In our study A. ciniformis could increase the amount of Bax protein and the cleaved form of PARP.

Our results are in agree with previous reports about the potency of $\mathrm{CH}_{2} \mathrm{Cl}_{2}$ extracts of different species, which may point to the similar chemicals present in the various species of the genus Artemisia that are responsible for cytotoxic effects.

Taken together, we can introduce A. ciniformis as a potent plant with cytotoxic effects against human leukemia cell lines. However, further analytical and mechanistic studies on the plant and its various species are essential to fully identify the chemicals responsible for this cytotoxic effect and to understand the pathway affected by the plant.

\section{Acknowledgements}

The authors would like to thank Mr. M. Malaekeh for his assistance in flow cytometry. This work was supported by grants (No. 910238) from Research Affairs of Mashhad University of Medical Sciences as a part of Pharm. D. thesis.

\section{References}

Abad MJ, Bedoya LM, Apaza L, et al (2012). The Artemisia L. genus, a review of bioactive essential oils. Molecules, 17, 2542-66.

Aniya Y, Shimabukuro M, Shimoji M, et al (2000). Antioxidant and hepatoprotective actions of the medicinal herb Artemisia campestris from the Okinawa Islands. Biol Pharm Bull, 23, 309-12.

Bora KS, Sharma A(2011). The genus Artemisia, a comprehensive review. Pharm Biol, 49, 101-9.

Cerella C, Teiten MH, Radogna F, et al (2014). From nature to bedside, Pro-survival and cell death mechanisms as therapeutic targets in cancer treatment. Biotechnol Adv.

Cha JD, Moon SE, Kim HY, et al (2009). Essential oil of Artemisia capillaris induces apoptosis in $\mathrm{KB}$ cells via mitochondrial stress and caspase activation mediated by MAPK-stimulated signaling pathway. J Food Sci, 74, 75-81.

Colditz GA, Wei EK (2012). Preventability of cancer, the relative contributions of biologic and social and physical environmental determinants of cancer mortality. Annu Rev 
Public Health, 33, 137-56.

Efferth T, Herrmann F, Tahrani A, et al (2011). Cytotoxic activity of secondary metabolites derived from Artemisia annua $\mathrm{L}$. towards cancer cells in comparison to its designated active constituent artemisinin. Phytomed, 18, 959-69.

Emami SA, Aghazari F. (2011). Les Phanerogames Endemiques de la Flore d'Iran. Teheran, Publications de I'Universite de Teheran,

Emami SA, Taghizadeh Rabe SZ, Ahi A, et al (2012). Inhibitory activity of eleven Artemisia species from Iran against Leishmania major parasites. Iran J Basic Med Sci, 15, 807-11.

Emami SA, Zamani Taghizadeh Rabe SH, Ahi A, et al (2010). Study on toxic effects of Artemisisa spp. fractions from Iran on human cancer cell lines. J Zanjan Univ Med Sci, 18, 58-67.

Fasinu, Orisakwe (2013). Heavy metal pollution in sub-Saharan Africa and possible implications in cancer epidemiology. Asian Pac J Cancer Prev, 14, 3393-402.

Firouzni A, Vahedi H, Sabbaghi F, et al (2008). Composition of the essential oil of Artemisia ciniformis, A. kopetdaghensis, and A. khorasanica in Iran. Chem Nat Compd, 44, 804-6.

Ghahreman A, Attar F. (1999). Biodiversity of plant species in Iran. Tehran, Tehran University Publication.

Gilani AH, Yaeesh S, Jamal Q, et al (2005). Hepatoprotective activity of aqueous-methanol extract of Artemisia vulgaris. Phytother Res, 19, 170-2.

Jiang W, Huang Y, Wang JP, Yu XY, Zhang LY. (2013). The synergistic anticancer effect of artesunate combined with allicin in osteosarcoma cell line in vitro and in vivo. Asian Pac J Cancer Prev, 14, 4615-9.

Judzentiene A, Budiene J, Gircyte R, et al (2012). Toxic activity and chemical composition of Lithuanian wormwood, et al (Artemisia absinthium L.)., essential oils. Rec Nat Prod, 6, 180-3.

Kordali S, Cakir A, Mavi A, et al (2005a). Screening of chemical composition and antifungal and antioxidant activities of the essential oils from three Turkish Artemisia species. J Agric Food Chem, 53, 1408-16.

Kordali S, Kotan R, Mavi A, et al (2005b). Determination of the chemical composition and antioxidant activity of the essential oil of Artemisia dracunculus and of the antifungal and antibacterial activities of Turkish Artemisia absinthium, A. dracunculus, Artemisia santonicum, and Artemisia spicigera essential oils. J Agric Food Chem, 53, 9452-8.

Lee TK, Vairappan CS. (2011). Antioxidant, antibacterial and cytotoxic activities of essential oils and ethanol extracts of selected South East Asian herbs. J Med Plants Res, 5, 5284-90.

Liu Y, Cui YF. (2013). Synergism of cytotoxicity effects of triptolide and artesunate combination treatment in pancreatic cancer cell lines. Asian Pac J Cancer Prev, 14, 5243-8.

Mojarrab M, Jamshidi M, Ahmadi F, et al (2013). Extracts of Artemisia ciniformis protect cytotoxicity induced by hydrogen peroxide in $\mathrm{H} 9 \mathrm{c} 2$ cardiac muscle cells through inhibition of reactive oxygen species. Adv Pharmacol Sci, Article ID 141683.

Munker R, Marini F, Jiang S, et al (1997). Expression of CD95 (FAS), by gene transfer does not sensitize K562 to Faskilling. Hematol Cell Ther, 39, 75-8.

Nicoletti I, Migliorati G, Pagliacci MC, et al (1991). A rapid and simple method for measuring thymocyte apoptosis by propidium iodide staining and flow cytometry. J Immunol Methods, 139, 271-9.

O'Brien J, Wilson I, Orton T, et al (2000). Investigation of the Alamar Blue (resazurin), fluorescent dye for the assessment of mammalian cell cytotoxicity. Eur J Biochem, 267, 5421-6.
Parsons MJ, Green DR. (2010). Mitochondria in cell death. Essays Biochem, 47, 99-114.

Piao GC, Li YX, Yuan HD, et al (2012). Cytotoxic fraction from Artemisia sacrorum Ledeb. against three human cancer cell lines and separation and identification of its compounds. Nat Prod Res, 26, 1483-91.

Rashid S, Rather MA, Shah WA, et al (2013). Chemical composition, antimicrobial, cytotoxic and antioxidant activities of the essential oil of Artemisia indica Willd. Food Chem, 138, 693-700.

Renault TT, Manon S. (2011). Bax, addressed to kill. Biochimie, 93, 1379-91.

Rustaiyan A, Masoudi S, Kazemi M. (2007). Volatile oils constituents from different parts of Artemisia ciniformis Krasch. et M. Pop. ex Poljak and Artemisia incana Druce. from Iran. J Essential Oil Res, 19, 548-51.

Sehitoglu MH, Farooqi AA, Qureshi MZ, et al (2014). Anthocyanins: targeting of signaling networks in cancer cells. Asian Pac J Cancer Prev, 15, 2379-81.

Singh NP, Ferreira JFS, Park JS, et al (2011). Cytotoxicity of ethanolic extracts of Artemisia annua to molt-4 human leukemia cells. Planta Med, 77, 1788-93.

Spies L, Koekemoer TC, Sowemimo AA, et al (2013). Caspasedependent apoptosis is induced by Artemisia afra Jacq. ex Willd in a mitochondria-dependent manner after G2/M arrest. $S$ Afr J Bot, 84, 104-9.

Taghizadeh Rabe SZ, Mahmoudi M, Ahi A, et al (2011). Antiproliferative effects of extracts from Iranian Artemisia species on cancer cell lines. Pharm Biol, 49, 962-9.

Tan RX, Tang HQ, Hu J, et al (1998). Lignans and sesquiterpene lactones from Artemisia sieversiana and Inula racemosa. Phytochemistry, 49, 157-61.

Tayarani-Najaran Z, Sareban M, Gholami A, et al (2013). Cytotoxic and apoptotic effects of different extracts of Artemisia turanica Krasch. on K562 and HL-60 cell lines. Scientific World J, 2013, 628073.

Tayarani-Najaran Z, Emami SA (2011). Cytotoxic Plants, Potential Uses in Prevention and Treatment of Cancer, Current Cancer Treatment-Novel Beyond Conventional Approaches, O. Ozdemir (editor), ISBN, 978-953-307397-2, InTech.

Tilaoui M, Mouse HA, Jaafari A, et al (2011). Chemical composition and antiproliferative activity of essential oil from aerial parts of a medicinal herb Artemisia herba-alba. Rev Bras Farmacogn, 21, 781-5.

Wegiera M, Smolarz HD, Jedruch M, et al (2012). Cytotoxic effect of some medicinal plants from Asteraceae family on J-45.01 leukemic cell line-Pilot study. Acta Pol Pharm, 69, 263-8. 